\title{
The Questionnaire about Interpersonal Difficulties for Adolescents: Reliability and Validity Evidence in Colombian Adolescents*
}

El Cuestionario de Dificultades Interpersonales para adolescentes:
evidencia de fiabilidad y validez en una muestra colombiana

Recibido: abril 15 de 2013 | Revisado: mayo 5 de 2013 | Aceptado: junio 5 de 2013

\author{
JESÚS REDONDO** \\ Universidad Pontificia Bolivariana, Bucaramanga, Colombia \\ BEATRIZ DELGADO **** \\ Universidad de Alicante, Alicante, España \\ CÁNDIDO J. INGLÉS ***** \\ MARÍA D. HidALGO ****** \\ Universidad de Murcia, Murcia, España \\ JosÉ M. GARCÍA-FERNÁNDEZ ******* \\ Universidad de Alicante, Alicante, España \\ María C. MartínEZ-MONTEAGUDO ******** \\ Universidad Miguel Hernández de Elche, Alicante, España
}

doi:10.11144/Javeriana.UPSY13-2.qida

Para citar este artículo: Redondo, J., Delgado, B., Inglés, C., Hidalgo, M. D., García-Fernández, J. M., \& Martínez-Monteagudo, M. C., (2014). The Questionnaire about Interpersonal Difficulties for Adolescents: Reliability and validity evidence in Colombian adolescents. Universitas Psychologica, 13(2), 467-476. doi:10.11144/Javeriana.UPSY13-2.qida

* Artículo de investigación en psicometría.

** Department of Psychology, Pontifical Bolivarian University, Km. 7, road Piedecuesta. Bucaramanga (Santander),Colombia.E-mail: jesus.redondo@upb. edu.co

**** Corresponding author. Department of Developmental Psychology and Didactics, University of Alicante, POBox 99, 03080, Alicante, Spain. Telephone: +34 965903400 - Ext. 1271. Fax: +34 9659098 86.Email: beatriz.delgado@ua.es

**we* Department of Health Psychology, Miguel Hernandez University of Elche, Avda. Universidad, s/n. 03202 Elche, Alicante, Spain, E-mail: cjingles@umh.es.

****** Department of Basic Psychology and Methodology, University of Murcia, Faculty of Psychology, Campus of Espinardo, 30100, Murcia, Spain. E-mail: mdhidalgo@um.es.

**:***: Department of Developmental Psychology and Didactics, University of Alicante, Ap. Correos 99, 03080, Alicante, Spain. E-mail: josemagf@ua.es.

*************arthent of Health Psychology, Miguel Hernandez University of Elche, Avda. Universidad, s/n. 03202 Elche, Alicante, Spain, E-mail: maria.mmonteagudo@umh.es.

\begin{abstract}
A B S T R A C T
The aim of this study was to analyze reliability and validity evidence of scores on the Colombian version of the Questionnaire about Interpersonal Difficulties for Adolescents (QIDA) in a sample of 1,628 adolescents (65.7\% boys), ranging in age from 12 to 18 years. Confirmatory factor analyses replicated the correlated five-factor structure of the QIDA: Assertiveness, Heterosexual Relationships, Public Speaking, Family Relationships, and Close Friendships. Internal consistency for the QIDA and subscales scores was excellent. Girls reported higher level of perceived anxiety in heterosexual relationships, whereas boys showed more anxiety in close friendships and decreased interpersonal anxiety during adolescence. Results support the reliability and validity of the scores on the Colombian version of the QIDA. Keywords
\end{abstract}

Adolescence, interpersonal difficulties, social fears, self-report, Colombia.

\section{RES U MEN}

Este objetivo de este estudio fue analizar la evidencia de fiabilidad y validez de las puntuaciones de la versión colombiana del Cuestionario de Dificultades Interpersonales para Adolescentes (QIDA) en una muestra de 1.628 adolescentes (65.7\% chicos) de 12 a 18 años. Los análisis factoriales confirmatorios replicaron la estructura factorial de cinco factores relacionados: Asertividad, Relaciones Heterosexuales, Hablar en Público, Relaciones Familiares y Amigos Íntimos. La consistencia interna del QIDA y sus subescalas fue excelente. Las chicas informaron mayores niveles de ansiedad percibida en relaciones heterosexuales, mientras los chicos mostraron más ansiedad en relaciones con amigos íntimos. La ansiedad interpersonal disminuyó durante la adolescencia. Los resultados apoyan la fiabilidad y validez de las puntuaciones de la versión colombiana del QIDA.

Palabras clave

Adolescencia, dificultades interpersonales, miedos sociales, autoinforme, Colombia. 
Jesús Redondo, Beatriz Delgado, José M. García-Fernández, Cándido J. Inglés, María C. Martínez-Monteagudo, María D. Hidalgo

Adolescence is a developmental stage characterized by important changes in social relationships. New social demands (e.g. dates, school exhibition, romantic relationships, friends) require adolescents to show greater independence in their social interactions and this favors the onset of interpersonal anxiety and social fears in those young people who find social interaction more difficult (Detweiler, Comer, \& Albano, 2010). Impairments and anxiety in social relationships are a common problem in adolescence (e.g., Chavira, Stein, Bailey, \& Stein, 2004; Inglés, Martínez-Monteagudo et al., 2008) and they are related to a large problems including drug consumption (e.g. Camacho, 2005; Wittchen, Stein, \& Kessler, 1999), victimization, social rejection and isolation (e.g., Inglés, Delgado, García-Fernández, Ruíz-Esteban, \& Díaz-Herrero, 2010; Van Zalk, Van Zalk, Kerr, \& Stattin, 2011), negative self-concept and low self-esteem (e.g. Delgado, Inglés, \& García-Fernández, 2013; Prinstein \& La Greca, 2002), poor academic achievement and early dropout (e.g. Bernstein, Bernat, Davis, \& Layne, 2008; Delgado, Inglés, \& Garcia-Fernandez, in press), and several emotional and anxiety disorders (e.g. Bernstein et al., 2008; Wittchen et al., 1999). For these reasons, the assessment of anxiety in social situations during adolescence has garnered considerable attention in last decades (see Inglés, Méndez, Hidalgo, Rosa, \& Orgilés, 2003; GarcíaLópez, Olivares, \& Vera-Villarroel, 2003; Tulbure, Szentagotai, Dobrean, \& David, 2012).

Despite this fact, these is a lack of psychometrically sound self-reports measures to assess interpersonal anxiety identifying different contexts and social behaviors in Colombian adolescents. Currently, there are several measures of social anxiety for adults developed by Colombian researchers (Brief Self-report Questionnaire for Social Phobia [BSQ-SP]; Rey-Anacona, Mejía, \& Montoya, 2008) or adaptations of English or Spanish questionnaires as the Social Anxiety and Distress Scale (SAD), the Fear of Negative Evaluation Scale (FNE) (Chaves \& Castaño, 2008; Carretero-Dios, Ruch, Agudelo, Platt, \& Proyer, 2010), and the Social Anxiety Questionnaire for Adults ([SAQ-A]; Caballo, Salazar, Irurtia, Arias,
\& Hofmann, 2012). However, to our knowledge, currently, there are no self-reports to assess interpersonal anxiety in Colombian adolescents. This is even more surprising when considering the appreciable prevalence of social anxiety in university students (10.3-10.9\%; Camacho, 2005; Londoño et al., 2010; Rey-Anacona et al., 2008) and adults in Colombia (5.1\%; Ministerio de Protección Social, 2004), the chronic course of interpersonal anxiety if untreated in adolescence (e.g. Keller, 2003), and the large personal, social, academic and job impairment of social anxious persons (e.g. Londoño et al., 2010; Robles, Espinosa, Padilla, Álvarez, \& Páez, 2008). Therefore, the first purpose of this study was to examine the psychometrical properties of scores on the Questionnaire about Interpersonal Difficulties for Adolescents (QIDA; Inglés, Hidalgo \& Méndez, 2005) in a representative sample of Colombian adolescents.

The QIDA was selected to be adapted into Colombian language because this instrument is a well-developed, widely used, and one of the most empirically supported measures of interpersonal anxiety in adolescence (e.g., Inglés et al., 2003; Tulbure et al., 2012). The QIDA is a 36-items self-report instrument designed to measure the interpersonal anxiety level perceived by adolescents in a wide range of relationships with people of different ages, gender, levels of authority and intimacy in several contexts: family, school, friends, opposite sex peers, and situations in the street, shops and public buildings. The QIDA provides important information for adolescents, educational and clinical psychologists, and researchers. This instrument can be used as a screening measure to identify social situations and relationships that adolescents find troublesome, which may serve as important target areas in social skills training programs (Inglés, 2003).

The psychometric properties of scores on the QIDA have proven to be satisfactory in several samples of Spanish adolescents (Inglés et al., 2005; Inglés, Marzo, Hidalgo, Zhou, \& García-Fernández, 2008; Méndez, Inglés, \& Hidalgo, 2002). Inglés et al. (2005) performed a confirmatory factor analysis and reported a correlated five-factor structure for the QIDA in a large Spanish adolescent sam- 
ple: Assertiveness (AS), consisting of 16 items about anxiety in making complaints, the defence of one's rights and interests, rejecting unreasonable requests, and asking service staff (waiters, shop assistants, etc.) and strangers in the street for information; Heterosexual Relationships (HR), consisting of seven items about anxiety in heterosexual relationships (having a date, giving compliments, etc.); Public Speaking (PS), consisting of five items describing situations which put the adolescent in front of a large group of people or an audience; Family Relationships (FR), consisting of four items about anxiety of being assertive in a family environment; and Close Friendships (CF), consisting of four items about anxiety in giving thanks, apologizing, and handling criticism with close friends. Inglés et al. (2005) also found internal consistency coefficients (Cronbach's alpha) appropriate and test-retest reliability, over a 2-week period, adequate. Correlations between the QIDA and the Personal Report of Confidence as Speaker, the Social Phobia and Anxiety Inventory, and the Eysenck Personality Questionnaire were statistically significant. Construct validity was also supported by marked differences in QIDA scores for adolescents with and without social phobia.

Furthermore, since its development, the QIDA has been translated and their psychometric properties have been examined for adolescents in China (Inglés, Marzo et al., 2008), Portugal (Inglés et al., 2008), Iran (Shokri et al., 2010), Slovenia (Zupancic et al., 2011) and France (Inglés et al., 2011). These studies showed similar reliability coefficients and similar validity evidence based on internal structure drawn from the scores on the QIDA (i.e., correlated five-factor structure) to that found by the original authors (Inglés et al., 2005).

Méndez et al. (2002), using a sample of Spanish adolescents, found gender and age differences in interpersonal anxiety based on scores of the QIDA. Specifically, girls reported greater interpersonal anxiety in general and in the most stressful relationships (assertiveness, opposite sex, public speaking), whereas boys reported more anxiety in the easiest relationships (family, friends). In this line, Caballo et al. (2008), using Social Anxiety Questionnaire for Adults (SAQ-A) in a sample of 1613 Colombian adults ( $M=25.06$ years), also found that women report more anxiety than men in interactions with the opposite sex and strangers, public speaking, assertive expression, criticism and embarrassment and awkward behavior. Furthermore, Méndez el al. (2002) found interpersonal anxiety increased overall with age and specifically in assertion, with the opposite sex, speaking in public and with friends, above all in mid-adolescence, although they decreased in family relationships. However, the magnitude or effect sizes for all gender and age differences were small or very small.

The first purpose of this research is to examine the validity and reliability evidence of scores drawn from the scores on the QIDA in a sample of Colombian adolescents. Furthermore, the second aim is to analyze gender and age differences in interpersonal anxiety in this sample.

Based on this previous research, the following hypotheses were derived:

1. It is expected to replicate the correlated five-factor structure and internal consistency reliability of scores on the Colombian version of the QIDA.

2. Bearing in mind that interpersonal anxiety shown significant cultural variations (e.g. Essau et al., 2012; Hofmann, Asnaani, \& Hinton, 2010; Inglés, Marzo et al., 2008), and no previous studies on gender and age differences in interpersonal anxiety in samples of Colombian adolescents have been published, we consider the hypotheses on gender and age differences in this sample of Colombian adolescents as open research questions.

\section{Method}

\section{Participants}

Participants were randomly selected students from two public and private secondary schools in the city of Pasto (Nariño). The initial sample consisted of 1,993 high school students from ages 12 to 18 . In order to avoid missing data, 251 (12.6\%) students were excluded from the study because their answers were incomplete and 114 (5.7\%) student were excluded 
Jesús Redondo, Beatriz Delgado, José M. García-Fernández, Cándido J. Inglés, María C. Martínez-Monteagudo, María D. Hidalgo

because their parents did not provide informed written consent. All the students participated voluntarily, and no student declined to participate. The final sample was comprised of 1,628 students (1,069 boys and 559 girls). Ages ranged from 12 to 18 years $(M=14.04 ; S D=1.56) .40 .4 \%$ of the subjects were between $12-13$ years $(24.8 \%$ boys and $15.6 \%$ girls), $37.8 \%$ were between $14-15$ years $(24.6 \%$ boys and $13.2 \%$ girls), and $21.7 \%$ were between 16 18 years $(16.2 \%$ boys and $5.5 \%$ girls).

\section{Measure}

Questionnaire about Interpersonal Difficulties for Adolescents ([QIDA]; Inglés et al., 2005). The QIDA is a 36-item self-report measure developed to measure interpersonal anxiety in adolescence. There are separate versions for male and female respondents that are identical except for the gender of nouns and pronouns. Each item is rated on a 5 point Likert scale according to the difficulty of each situation and social relationship $(0=$ no difficulty; $4=$ maximum difficulty). The QIDA consist of a total score and five subscale scores: AS, HR, PR, $\mathrm{FR}$, and CF. As scores increase, so do indications of interpersonal anxiety.

Due to original version of QIDA is written in Spanish language, the Colombian translation of QIDA was conducted by means of two Colombian interpreters having a university degree in Spanish language and knowledge of Spanish culture. As result, the items vocabulary were modified adjusting to Colombian language: "camarero" was modified to "mesero" (Items 4, 10, 15, 20), "tres euros" was modified to "tres mil pesos" (Item 1), "cola" was modified to "fila" (Item 6), "autobus" was modified to "bus" (Item 8), "chico/chica" were modified to “jóven" (Items 8 11, 21, 26, 32, 36), "lotería and viaje de estudios" were modified to "rifa and paseo del colegio" (Item 14), "pizarra" was modified to "tablero" (Item 16), "libreta de ahorros" was modified to "cuenta de ahorros" (Item 18), "excursion" was modified to "paseo" (Item 31), "refresco and zumo" was modified to "gaseosa and jugo" (Item 35). The Colombian translation is available from the first author on request.

\section{Procedure}

After obtaining the approval and cooperation of the head teachers and student guidance counsellors at the schools and written informed consent from the parents, students answered the questionnaire anonymously whilst together in class. The researchers were present during administration of the QIDA to resolve any doubts and ensure that the participants were completing their questionnaire individually. The average administration time was 15 minutes.

\section{Results}

\section{Normality and Assumptions}

Scores on the QIDA had univariate skewness statistics ranging from 0.03 (item 13) to 2.33 (item 22) with standard error of 0.07 , whereas univariate kurtosis statistics ranged from -1.35 (item 36) to 4.6 (item 22) with standard error of 0.14. Similar results were found for the samples by gender and age. Furthermore, values of Mardia's normalized multivariate kurtosis were: 153.46 (total sample), 123.32 (boys), 80.89 (girls), 79.26 (12- to 13-yearolds), 78.29 (14- to 15-year-olds), and 64.66 (16- to 18 -year-olds). These values support the presence of severe non-normality in the distribution of QIDA across these subsamples. Therefore, following the procedure outlined by Finney and DiStefano (2006), confirmatory factor analyses (CFA) were conducted using robust maximum likehood (ML) estimation method.

\section{Validity Evidence Based on the Internal \\ Structure of Scores on the QIDA: Confirmatory Factor Analyses}

Three factor models were tested with the total sample, with boys and girls separately, and with each of the age groups: the null model $\left(\mathrm{M}_{0}\right)$, which assumes the maximum independence among items (the model without a factor structure); the one-factor model $\left(\mathrm{M}_{1}\right)$, which accept that all items will satu- 
rate in the same factor (i.e., interpersonal anxiety), and the five-factor model $\left(\mathrm{M}_{5}\right)$, which is based on the results found by Inglés et al. (2005), allowing intercorrelations among the five factors.

To assess the adequacy of the models the robust comparative fit indexes R-CFI and R-RMSEA were examined. A good fit is indicated by CFI values greater than 0.9 or close to 0.95 and standardized root mean square residual (S-RMR) values less than 0.08. A root mean square error of approximation (R-RMSEA) value less than 0.06 indicates a good fit (Hu \& Bentler, 1999).

The Satorra-Bentler (SB) scaled $\chi^{2}\left(\mathrm{SB} \chi^{2}\right)$ modified test revealed that the best fitting overall of the correlated five-factor model for all samples (see Table 1), with reasonable values in all indexes (S-RMR $=0.04-0.06$; RCFI $=0.9-0.92 ;$ R-RMSEA $=0.03$ 0.04). For the total sample, the $M_{5}$ represented a significant improvement over the $\mathrm{M}_{0}\left(\chi^{2}(46)=\right.$ $14347.09, p<0.0001)$ and $M_{1}\left(\chi^{2}(10)=3376.30\right.$, $p<0.0001)$ model. These results were similar for the samples by gender and age (see Table 1).
For Pearson correlation coefficients, the criteria proposed by Cohen (1988) was adopted in this study, in which values between 0.1-0.29, 0.3-0.49 and $>0.5$ indicate a small, moderate and high magnitude, respectively. Thus, correlations between scores on the QIDA subscales were relatively high in most cases (see Table 2). The exceptions were the associations of HR with PS, FR and CF factors and PS with FR factor which indicated an average magnitude in most of correlations, whereas the association between HR and CF factors was small in the sample of girls. The average intercorrelation was 0.59 for total sample and ranged between 0.55 and 0.63 for the gender and age groups.

\section{Reliability Evidence of Scores on the QIDA}

Cronbach's alpha was: 0.91 (QIDA), 0.86 (HR), 0.83 (AS), 0.72 (PS), 0.71 (FR), and 0.7 (CF) for the total sample. The internal consistency coefficients for QIDA subscales and the total score were also calculated separately for girls and boys and for

TABLE 1

Fit Statistics for Confirmatory Factor Models

\begin{tabular}{llcccccc}
\hline \multicolumn{1}{c}{ Sample } & \multicolumn{1}{c}{ Model } & S-B $\chi^{2}$ & $d f$ & $p$ & S-RMR & R-CFI & R-RMSEA \\
\hline Total sample & Null $\left(\mathrm{M}_{0}\right)$ & 12737.76 & 630 & 0 & & & 0 \\
$(\mathrm{~N}=1628)$ & One latent variable $\left(\mathrm{M}_{1}\right)$ & 4208.33 & 594 & 0 & 0.07 & 0.70 & 0.06 \\
& Five latent variables $\left(\mathrm{M}_{5}\right)$ & 1622.25 & 584 & 0 & 0.04 & 0.91 & 0.03 \\
\hline Boys & Null $\left(\mathrm{M}_{0}\right)$ & 8254.24 & 630 & 0 & & & 0 \\
$(\mathrm{~N}=1069)$ & One latent variable $\left(\mathrm{M}_{1}\right)$ & 2746.76 & 594 & 0 & 0.07 & 0.72 & 0.06 \\
& Five latent variables $\left(\mathrm{M}_{5}\right)$ & 1219.27 & 584 & 0 & 0.04 & 0.92 & 0.03 \\
\hline Girls & Null $\left(\mathrm{M}_{0}\right)$ & 5064.43 & 630 & 0 & & & 0 \\
$(\mathrm{~N}=559)$ & One latent variable $\left(\mathrm{M}_{1}\right)$ & 1889.87 & 594 & 0 & 0.08 & 0.71 & 0.06 \\
& Five latent variables $\left(\mathrm{M}_{5}\right)$ & 1022.47 & 584 & 0 & 0.06 & 0.9 & 0.04 \\
\hline $12-13$ years & Null $\left(\mathrm{M}_{0}\right)$ & 5537.38 & 630 & 0 & & & 0 \\
$(\mathrm{~N}=658)$ & One latent variable $\left(\mathrm{M}_{1}\right)$ & 2062.41 & 594 & 0 & 0.07 & 0.7 & 0.06 \\
& Five latent variables $\left(\mathrm{M}_{5}\right)$ & 1033.03 & 584 & 0 & 0.05 & 0.91 & 0.03 \\
$14-15$ years & Null $(\mathrm{M} 0)$ & 5307.21 & 630 & 0 & & & 0 \\
$(\mathrm{~N}=616)$ & One latent variable $\left(\mathrm{M}_{1}\right)$ & 2144.61 & 594 & 0 & 0.08 & 0.67 & 0.07 \\
& Five latent variables $\left(\mathrm{M}_{5}\right)$ & 984.1 & 584 & 0 & 0.05 & 0.91 & 0.03 \\
$16-18$ years & Null $(\mathrm{M} 0)$ & 3169.4 & 630 & 0 & & & 0 \\
$(\mathrm{~N}=354)$ & One latent variable $\left(\mathrm{M}_{1}\right)$ & 1293.71 & 594 & 0 & 0.07 & 0.72 & 0.06 \\
& Five latent variables $\left(\mathrm{M}_{5}\right)$ & 816.9 & 584 & 0 & 0.06 & 0.91 & 0.03 \\
\hline
\end{tabular}

Note. $\chi^{2}=$ Satorra-Bentler Chi-Square, $d f=$ degrees of freedom, $p=$ level of significance, S-RMR $=$ Square-Root Mean Residual, R-CFI = Robust Comparative Fit Index, R-RMSEA = Root Mean Square Error of Approximation.

Source: own work 
Jesús Redondo, Beatriz Delgado, José M. García-Fernández, Cándido J. Inglés, María C. Martínez-Monteagudo, María D. Hidalgo

TABLE 2

Correlations in the CFA between Latent Dimensions of the QIDA

\begin{tabular}{ccccccc}
\hline & Total Sample & Girls & Boys & $11-13$ years & $14-15$ years & $16-18$ years \\
\hline AS-HR & 0.559 & 0.604 & 0.565 & 0.557 & 0.503 & 0.613 \\
AS-PS & 0.704 & 0.684 & 0.72 & 0.735 & 0.667 & 0.695 \\
AS-FR & 0.717 & 0.683 & 0.739 & 0.756 & 0.682 & 0.66 \\
AS-CF & 0.738 & 0.681 & 0.782 & 0.745 & 0.718 & 0.794 \\
HR-PS & 0.46 & 0.427 & 0.493 & 0.437 & 0.43 & 0.539 \\
HR-FR & 0.404 & 0.363 & 0.451 & 0.382 & 0.369 & 0.412 \\
HR-CF & 0.361 & 0.266 & 0.486 & 0.336 & 0.332 & 0.483 \\
PS-FR & 0.5 & 0.437 & 0.547 & 0.542 & 0.448 & 0.503 \\
PS-CF & 0.629 & 0.571 & 0.68 & 0.658 & 0.613 & 0.607 \\
FR-CF & 0.799 & 0.813 & 0.798 & 0.834 & 0.79 & 0.749 \\
\hline
\end{tabular}

All correlations are significant at level 0.001, AS $=$ Assertiveness, $H R=$ Heterosexual Relationships, $P S=$ Public Speaking, $\mathrm{FR}=$ Family Relationships, $\mathrm{CF}=$ Close Friendships.

Source: own work

\section{TABLE 3}

Gender Differences of Scores on the QIDA Scales

\begin{tabular}{|c|c|c|c|c|c|c|c|}
\hline \multirow{3}{*}{ QIDA dimensions } & \multicolumn{4}{|c|}{ Gender } & \multirow[b]{3}{*}{ F } & \multirow[b]{3}{*}{$p$} & \multirow[b]{3}{*}{$d$} \\
\hline & \multicolumn{2}{|c|}{ Boys } & \multicolumn{2}{|c|}{ Girls } & & & \\
\hline & $M$ & SD & $M$ & SD & & & \\
\hline Assertiveness & 18.89 & 10.1 & 19.47 & 11.43 & 0.001 & 0.981 & - \\
\hline Heterosexual Relationships & 10.59 & 6.25 & 14.36 & 6.6 & 87.05 & $<0.001$ & -0.59 \\
\hline Public Speaking & 60.68 & 40.06 & 70.05 & 40.68 & 10.424 & 0.233 & 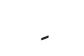 \\
\hline Family Relationships & 2.99 & 3.23 & 3.06 & 3.52 & 0.003 & 0.958 & - \\
\hline Close Friendships & 3.02 & 3.09 & 2.46 & 3.14 & 13.53 & $<0.001$ & 0.18 \\
\hline Total QIDA & 42.17 & 21.34 & 46.39 & 22.92 & 6.65 & 0.01 & -0.19 \\
\hline
\end{tabular}

Source: own work

the different age groups, ranged from 0.81 to 0.85 for AS, 0.81 to 0.87 for HR, 0.7 to 0.78 for PS, 0.71 to 0.73 for FR, 0.7 to 0.72 for $\mathrm{CF}$, and 0.91 for the total QIDA.

Gender and Age Differences in Interpersonal Difficulties of Colombian Adolescents

To evaluate gender and age differences in the QIDA and its five domains, Gender by Age group $(2 \times 3)$ two-way ANOVAs were performed across the scale scores (see Tables 3 and 4). The magnitude of the differences was analysed, obtaining effect sizes $(d)$. Cohen (1988) suggested that, for the $F$ statistic (i.e., ANOVA), values ${ }^{3}>0.2$ and $<0.5$ indicate a small effect size, and values between 0.5-0.79 and $>0.8$ indicate a moderate and high effect size, respectively.

In comparison to boys, girls reported on significantly more overall interpersonal anxiety $\left(F_{(1,1622)}\right.$ $=6.65, p<0.05, d=-0.19)$, due to higher level of perceived anxiety in heterosexual relationships $\left(F_{(1,1622)}=87.05, p<0.001, d=-0.59\right)$. Furthermore, boys reported high level of interpersonal anxiety with close friends that girls $\left(F_{(1,1622)}=13.53\right.$, $p$ $<0.001)$. In this case, the effect size was found to be insignificant $(d=0.18)$.

All of the age differences were statistically significant. Self-reported interpersonal anxiety (QIDA total) significantly decreased with adolescents' age due mainly to age differences in AS, HR and FR (see Table 4). 
TABLE 4

Age Differences of Scores on the QIDA Scales

\begin{tabular}{lccccccccc}
\hline \multirow{2}{*}{ QIDA dimensions } & \multicolumn{9}{c}{ Age } \\
\cline { 2 - 8 } & \multicolumn{2}{c}{$12-13$ years } & \multicolumn{1}{c}{$14-15$ years } & \multicolumn{1}{c}{$16-18$ years } & & \multirow{2}{*}{$\eta^{2 \%}$} \\
\cline { 2 - 8 } & $\mathrm{M}$ & $\mathrm{SD}$ & $\mathrm{M}$ & $\mathrm{SD}$ & $\mathrm{M}$ & $\mathrm{SD}$ & & \\
\hline Assertiveness & 20.25 & 10.86 & 19.26 & 10.36 & 16.61 & 10 & $14.4^{\mathrm{a}}$ & 1.7 \\
Heterosexual Relationships & 12.93 & 7.32 & 11.94 & 6.81 & 9.84 & 6.25 & $14.96^{\mathrm{a}}$ & 1.8 \\
Public Speaking & 6.91 & 4.35 & 7.08 & 4.32 & 6.14 & 4.04 & $4.35^{\mathrm{a}}$ & 0.5 \\
Family Relationships & 3.61 & 3.53 & 2.86 & 3.22 & 2.16 & 2.9 & $18.76^{\mathrm{a}}$ & 2.3 \\
Close Friendships & 2.98 & 3.46 & 2.83 & 2.86 & 2.55 & 2.88 & $3.559^{\mathrm{b}}$ & 0.8 \\
Total QIDA & 46.69 & 22.88 & 43.97 & 21.03 & 37.31 & 20.58 & $18.16^{\mathrm{a}}$ & 2.2 \\
\hline
\end{tabular}

Note. Probability levels designated with "a" are significant at level 0.001 , and probability levels designated wit "b" are significant at level 0.05.

Source: own work

All of the age differences (effect size estimated by $\eta^{2}$ ) were small with age explaining at best $2.3 \%$ of the variance (FR) in scale scores. There were not significant interaction effects explaining. Post-hoc tests with Bonferroni correction revealed small but significant differences across most of the paired-comparisons in AS [16-18 years vs. $12-13$ years $(d=0.34)$ and $14-15$ years $(d=0.26)]$, HR [12-13 years vs. $14-15$ years $(d=0.14)$ and $16-18$ years $(d=0.44)$, and $14-15$ years vs. $16-18$ years $(d$ $=0.32)]$, PS [16-18 years vs. $12-13$ years $(d=0.18)$ and $14-15$ years $(d=0.22)]$, FR factors [ $12-13$ years vs. $14-15$ years $(d=0.22)$ and $16-18$ years $(d=0.44)$, and $14-15$ years vs. $16-18$ years $(d=0.23)]$ and QIDA total score $[16-18$ years vs. $12-13$ years $(d=$ $0.42)$ and $14-15$ years $(d=0.32)$ ], suggesting an age decrease of interpersonal anxiety over adolescence.

\section{Dicussion}

The need for come a valid and reliable instrument to assess interpersonal anxiety and to identify adolescents with impairments in social interaction in Colombian adolescent population has motivated this study. The first purpose was to examine the reliability and validity evidence drawn from the scores on the QIDA in a sample of Colombian adolescents. Overall, our findings provide initial support for the reliability and validity of scores on QIDA, and confirm the good psychometric properties of the measure to assess interpersonal anxiety in adolescence (Tulbure et al., 2012).
Confirmatory factor analyses replicated the correlated five-factor structure found in samples from the Spain (Inglés et al., 2005), China (Inglés, Marzo et al., 2008), Portugal (Inglés, Castanheira et al., 2008), Iran (Shokri et al., 2010), Slovenia (Zupancic et al., 2011) and France (Inglés, Delgado et al., 2011) supporting the first hypothesis. These results were also found by gender and age groups, bringing evidence of factor form invariance for the QIDA in different samples.

In line with previous studies in different samples (Inglés et al., 2005; Inglés, Marzo et al., 2008; Shokri et al., 2010; Zupancic et al., 2011), adequate reliability were found for Colombian version of QIDA. According rating criteria proposed by Hunsley and Marsh (2008) the internal consistence coefficients (Cronbach alpha) across genders and age groups was excellent for QIDA total score and ranged from adequate to excellent for QIDA subscales. In addition, the intercorrelations among the subscale scores of QIDA (mean 0.59) suggesting that the five domains are moderately related but represent different aspects of interpersonal anxiety, above all in associations between family relationships and relations with friends and impairment in public speaking. Similar results were obtained in previous studies (Inglés et al., 2005; Zupancic et al., 2011), supporting that conflicts with parents and friends are relatively less related with fear to public speaking and perceived difficulties with other sex people. 
Jesús Redondo, Beatriz Delgado, José M. García-Fernández, Cándido J. Inglés, María C. Martínez-Monteagudo, María D. Hidalgo

Colombian girls reported significantly more overall interpersonal anxiety and more perceived anxiety in heterosexual relationships and Colombian boys reported high level of anxiety with close friends. These results are consistent with research conducted in Spain (Méndez et al., 2002) and in Slovenia (Zupancic et al., 2011). However, we must be cautious in interpreting these differences since the effect size for QIDA and CF scores were insignificant $(d<0.2)$, so theoretical and practical relevance is questionable empirically (Cohen, 1988). Thus, we conclude that girls regarding boys perceive moderately more difficult to set up a link with other sex people, but the empirical relevance of gender differences for QIDA and CF scores in this sample is insufficient to consider different interventions for improve friendships between boys and girls.

Finally, differences in total QIDA score and all QIDA subscales across age groups were found. However, the post-hoc test did not find between means of CF subscale. Concretely, we found a small decreased from early and middle to late-adolescence for overall interpersonal anxiety, assertiveness and public speaking, and a decreased across all age groups for anxiety in heterosexual and family relationships. These findings are similar to Zupancic et al. (2011) study but only partially consistent to data of Méndez et al. (2002), supporting that interpersonal differences in Colombian population may interfering less to the extend that adolescents face for to new social relationships and responsibilities. This issue must be clarified in other samples (clinical and community) of Colombian adolescents.

This study presents some limitations which should be resolved for future research. First, despite our results show an adequate evidences of internal consistency reliability (items heterogeneity) and construct validity (factor structure) it would be require to use other designs of data collection for examine the reliability and validity evidence of the QIDA scores, for example, temporal stability, diagnostic utility for detect social anxious adolescents and correlations with similar and different assessment instruments. Additionally, to accumulate further construct validity it would be useful to analyze the measurement invariance of QIDA across gender and age groups in Colombian adolescents. Despite these limitations, the results of present study suggests that QIDA is a psychometrically adequate measure for assessing interpersonal anxiety in adolescence and support the use of scores on the QIDA in Colombian adolescent population.

\section{References}

Bernstein, G. A., Bernat, D. H., Davis, A. M., \& Layne, A. E. (2008). School-based interventions for anxious children: 3-, 6-, and 12-month follow-ups. Journal of the American Academy of Child $\mathcal{E}$ Adolescent Psychiatry, 47(9), 1039-1047.

Caballo, V. E., Salazar, I. S., Irurtia, M. J., Arias, B., \& Hofmann, S. G. (2012). The multidimensional nature and multicultural validity of a new measure of social anxiety: The Social Anxiety Questionnaire for Adults. Behavior Therapy, 43(2), 313-328.

Caballo, V. E., Salazar, I. S., Irurtia, M. J., Arias, B., Hofmann, S. G., \& CISO Research Team. (2008). Social anxiety in 18 nations: Sex and age differences. Behavioral Psychology, 16(2), 163-187.

Camacho, I. (2005). Consumo de alcohol en universitarios: relación funcional con los factores sociodemográficos, las expectativas y la ansiedad social. Acta Colombiana de Psicología, 13, 91-119.

Carretero-Dios, H., Ruch, W., Agudelo, D., Platt, T., \& Proyer, R. T. (2010). Fear of being laughed at and social anxiety: A preliminary psychometric study. Psychological Test and Assessment Modeling, 52(1), 108-124.

Colombia, Ministerio de Protección Social. (2005). Estudio nacional de salud mental. Colombia 2003. Cali, Co: Ministerio de Protección Social \& Fundación Fees Social.

Chaves, L., \& Castaño, C. M. (2008). Validación de las escalas de evitación, ansiedad social y temor a la evaluación negativa en población colombiana. Acta Colombiana de Psicología, 11, 65-76.

Chavira, D. A., Stein, M. B., Bailey, K., \& Stein, M. T. (2004). Comorbidity of generalized social anxiety disorder and depression in a pediatric primary care sample. Journal of Affective Disorders, 80(2-3), 163-171. http://dx.doi.org/10.1016/S01650327(03)00103-4 
Cohen, J. (1988). Statistical power analysis for the behavioral sciences. Hillsdale: Erlbaum.

Delgado, B., Inglés, C. J., \& García-Fernández, J. M. (2013). Social anxiety and self-concept in adolescence. Revista de Psicodidáctica, 18(1), 179-194. doi:10.1387/RevPsicodidact.6411

Delgado, B., Inglés, C. J., \& García-Fernández, J. M. (2014). Ansiedad social subclínica y rendimiento académico en la adolescencia: Análisis de sus implicaciones teórico-prácticas. Estudios de Psicología, 35 (1), 58-79. doi: 10.1080/02109395.2014.893649

Detweiler, M. F., Comer, J. S., \& Albano, A. M. (2010). Social anxiety in children and adolescents: Biological, developmental, and social considerations. In S. G. Hofmann \& P. M. DiBartolo (Eds.), Social anxiety: Clinical, developmental, and social perspectives (pp. 223-270). London: Elsevier.

Essau, C. A., Leung, P. W. L., Koydemir, S., Sasagawa, S., O'Callaghan, J., \& Bray, D. (2012). The impact of self-construals and perceived social norms on social anxiety in young adults: A cross-cultural comparison. International Journal of Culture and Mental Health, 5(1), 109-120.

Finney, S. J., \& DiStefano, C. (2006). Non-normal and categorical data in structural equation modeling. In G. R. Hancock \& R. O. Mueller (Eds.), Structural equation modelling: A second course (pp. 269-314). Greenwich: Information Age Publishing.

García-López, L. J., Olivares, J., \& Vera-Villarroel, P. E. (2003). Fobia social: revisión de los instrumentos de evaluación validados para población de lengua española. Revista Latinoamericana de Psicología, 35(2), 151-160.

Hofmann, S. G., Asnaani, A., \& Hinton, D. E. (2010). Cultural aspect in social anxiety and social anxiety disorder. Depression and Anxiety, 27(12), 1117-1127.

Hu, L., \& Bentler, P. (1999). Cut off criteria for fit indices in covariance structure analysis: conventional criteria versus new alternatives. Structural Equation Modeling, 6(1), 1-55.

Hunsley, J., \& Marsh, H. (2008). A guide to assessment that work. New York: Oxford University.

Inglés, C. J. (2003). Programa PEHIA: enseñanza de habilidades interpersonales para adolescentes. Madrid: Ediciones Pirámide.
Inglés, C. J., Castanheira, J., Ribeiro. F., \& GarcíaFernández, J. M. (2008). Preliminar psychometric properties of the Portuguese version of the Questionnarie about Interpersonal Difficulties for Adolescents. International Journal of Psychology, 43(3), 278-288.

Inglés, C. J., Delgado, B., García-Fernández, J. M., Ruiz-Esteban, C., \& Díaz-Herrero, A. (2010). Sociometric types and social interaction styles in a sample of Spanish adolescents. Spanish Journal of Psychology, 13(2), 728-738.

Inglés, C. J., Delgado, B., Hidalgo, M. D., García-Fernández, J. M., \& Prêteur, Y. (2011, April). Factorial structure and reliability of the French version of the Questionnaire about interpersonal difficulties for adolescents (QIDA): A pilot study. Paper presented at the Journées d'Études sur l'Adolescence of the European Association for Research on Adolescence, Toulouse, France.

Inglés, C. J., Hildago, M. D., \& Méndez, F. X. (2005). Interpersonal difficulties in adolescence: A new self-report measure. European Journal of Psychological Assessment, 21(1), 11-22.

Inglés, C. J., Martínez-Monteagudo, M. C., Delgado, B., Torregrosa, M. S., Redondo, J., Benavides, G., et al. (2008). Prevalencia de ansiedad social, conducta prosocial y conducta antisocial en una muestra de adolescentes españoles: un estudio comparativo. Infancia y Aprendizaje, 31(4), 449-461.

Inglés, C. J., Marzo, J. C., Hidalgo, M. D., Zhou, X., \& García-Fernández, J. M. (2008). Factorial invariance of the questionnaire about interpersonal difficulties for adolescents across Spanish and Chinese adolescent samples. Measurement and Evaluation in Counseling and Development, 41(2), 89-103.

Inglés, C. J., Méndez, F. X., Hidalgo, M. D., Rosa, A. I., \& Orgilés, M. (2003). Cuestionarios, inventarios y escalas de ansiedad social para adolescentes: una revisión crítica. Revista de Psicopatología y Psicología Clínica, 8(1), 1-21.

Keller, M. B. (2003). The lifelong course of social anxiety disorder: A clinical perspective. Acta Psychiatrica Scandinavica, 108(Suppl. 417), 85-94.

Londoño, N. H., Marín, C. A., Juárez, F., Palacio, J., Muñiz, O., Escobar, B., Herrón, I., et al. (2010). Factores de riesgo psicosociales y ambientales 
asociados a trastornos mentales. Suma Psicológica, 17(1), 59-68.

Méndez, F. X., Inglés, C. J., \& Hidalgo, M. D. (2002). Estrés en las relaciones interpersonales: un estudio descriptivo en la adolescencia. Ansiedad y Estrés, 8(1), 25-36.

Prinstein, M. J., \& La Greca, A. (2002). Peer crowd affiliation and internalizing distress in childhood and adolescence: A longitudinal folow-back study. Journal of Research on Adolescence, 12(3), 325-351.

Rey-Anacona, C. A., Mejía, D. C., \& Montoya, C. E. (2008). Evaluación de la confiabilidad y la validez de un cuestionario breve de autoinforme para el diagnóstico de la fobia social. Universitas Psychologica, 7(2), 477-491.

Robles, R., Espinosa, R. A., Padilla, A. C., Álvarez, M. A., \& Páez, F. (2008). Ansiedad social en estudiantes universitarios: prevalencia y variables psicosociales relacionadas. Psicología Iberoamericana, 16(1), 54-63.

Shokri, O., Abdolkhaleghi, M., Afzali, M., Gravand, F., Paeezi, M., \& Toolabi, S. (2010). Factor structure and psychometric properties of the Questionnaire about Interpersonal Difficulties for Adolescents in an Iranian sample. Journal of Iranian Psychologists, 6(24), 307-316.

Tulbure, B. T., Szentagotai, A., Dobrean, A., \& David, D. (2012). Evidence based clinical assessment of child and adolescent social phobia: A critical review of ratings scales. Child Psychiatry and Human Development, 43(5), 795-820.

Van Zalk, N.,Van Zalk, M., Kerr, M., \& Stattin, H. (2011). Social anxiety as a basis for friendship selection and socialization in adolescents' social networks. Journal of Personality, 79(3), 499-525.

Wittchen, H. U., Stein, M. B., \& Kessler, R. C. (1999). Social fears and social phobia in a community sample of adolescents and young adults: Prevalence, risk factors and co-morbidity. Psychological Medicine, 29(2), 309-323.

Zupancic, M., Inglés, C. J., Bajec, B., \& Puklek, M. (2011). Reliability and validity evidence of scores on the Slovene version of the Questionnaire about Interpersonal Difficulties for Adolescents. Child Psychiatry and Human Development, 42(3), 349-366. 